\title{
A Review of Long Term Turbidity Trends with Possible Reasons around the World
}

\author{
Ilknur Tuncer* \\ Institute of Marine Sciences and Technology, Turkey \\ *Corresponding author: Ilknur Tuncer, Institute of Marine Sciences and Technology, Turkey \\ Submission: 觜 August 21, 2017; Published: 㘹 September 25, 2017
}

\begin{abstract}
In this review, it was tried to summarize the long term turbidity trends in various environments around the world. It was found that there was a decreasing trend in water clarity for Baltic Sea, Dutch Wadden Sea, Black Sea, Adriatic Sea, Japanese coasts due to eutrophication, rapid industrialization, anthropogenic input, etc. throughout 1900s and when those effects were diminished as maintained in Norwegian and North Atlantic coasts by the introduction of waste treatment plants and the improvement of sewage systems, an increasing trend was obtained. Moreover, clear oceanic water intrusion into near shore regions also resulted in an increase in water clarity as seen in the coasts of Southern California. On the other hand, since coasts of Wales, UK consisted of inorganic sediments, rather than anthropogenic effects, wind was tested as the reason of turbidity by comparing with clear Spanish coasts and it was concluded that long term turbidity could be driven by long term local wind however wind could not cause turbidity without suspended particles in water.
\end{abstract}

Keywords: Turbidity; Water clarity; Suspended particles; Anthropogenic effects; Wind

\section{Introduction}

\section{Turbidity trends in different parts of the world}

Turbidity as a measure of water clarity, especially high turbidity reduces the amount of light penetrating water, photosynthesis, production of dissolved oxygen, disease resistance of fish, growth rates and egg development of especially benthic macro organisms.

In the Baltic Sea, phytoplankton biomass increased due to eutrophication and water clarity decreased between 1969 and 1991 [1]. A decreasing trend was observed in Omura Bay, Japan from 1945 to 1975 due to the rapid industrialization and population growth in the area [2]. Another decreasing trend was also seen in the Seto Inland Sea between 1926 and 1986 [3,4].

A rapid decrease in water clarity was measured between 1960s and 1980s in the Black Sea due to changes in the structure of the food web as introduction of the zooplanktivirous ctenophore, Mnemiopsisledyii Agassiz, resulting decline in zooplankton abundance and increase in phytoplankton stock [5]. Similarly, due to increased phytoplankton biomass which was related to the nutrient enrichment coming from the Po River discharge, transparency decreased from 1960 to 1982 in the northern Adriatic [6], in addition to the decrease seen in the eastern Adriatic due to eutrophication $[7,8]$.

Although no trend was obtained in the Marsdie between 1974 and 1990 a decreasing trend between 1930 and 1985 and an increase between 1985 and 1990 which was due to rapid decline in suspended matter in the water column was observed in the Dutch Wadden Sea [9]. On the other hand, the increase in water clarity in Santa Monica Bay in the Southern California Bight between 1972 and 1987 was not related to anthropogenic activities but to long time-scale fluctuations in the intrusion of clear oceanic water into near shore regions [10,11].

Increasing trends in water clarity were also observed in Norwegian coastal waters between 1960 and 1993 due to improvements in sewage treatment [12] and similarly due to the introduction of waste treatment plants, an increase in water clarity in Narragansett Bay between 1972 and 1996 was seen [1]. In spite of no overall trend observed in 1987-1997 for the Irish Sea, annual variations in turbidity were found as correlated with regional wind strength and thus it was suggested that the turbidity in coastal seas was controlled by climate [13].

While a decreasing trend in the water clarity of the Menai Strait, UK from the 1960s to1980s did not continue in the 1990s and 2000s [14], it was suggested that turbidity in the strait was mostly due to inorganic sediment, not organic or sewage and also the changes in turbidity were driven by changes in wind, in other words climate $[14,15]$. Similarly, since wind strength data over British Isles increased between 1960s and 1980s but decreased in 1990s [16] suggested that the wind speeds in 1990s could lead to reduced volumes of sediment stirred up by the winds blowing over the $[14,15]$.

As compared long term trends of the Menai Strait from 1961 to 2005 with Skomer Marine Nature Reserve (MNR) in UK and L'Estartit in Spain, an increasing trend was found between 1992 and 2005 for Skomer MNR in contrast to the decrease in water clarity of 
Spanish coasts from 1975 to 2005 [17]. Furthermore, when those turbidity trends were tested against wind speeds showing inverse relations for Gwynedd with a constant trend from 1961 to 2005, for Cardiff with a decreasing trend from 1996 to 2005 and for Barcelona with a decreasing trend from 1996 to 2004, respectively, it was concluded that long term turbidity could be driven by long term local wind however wind speed did not individually explain turbidity at least in the strait [17].

\section{Aim}

In this review, it was targeted to summarize the turbidity trends with their possible reasons in different regions of the world for further programming the areas to get rid of the environmental problems and then for sustainable management of environment.

\section{Conclusion}

In general, two factors which were anthropogenic effects and climate appeared as the reasons of the decreasing trend in water clarity. Thus, when anthropogenic factors were reduced by the help of sewage and waste water treatments and the decline in eutrophication etc., an increasing trend was observed. If the second effect such as wind was considered, then it was found that wind could not cause turbidity without suspended particles in water but enough amount of wind could make water having enough amounts of particles turbid.

\section{References}

1. Borkman DG, Smayda TJ (1998) Long term trends in water clarity revealed by Secchi-disk measurements in lower Narragansett Bay. ICES Journal of Marine Science 55(4): 668-679.

2. Iizuka S (1976) Succession of red tide organisms in Omura Bay with relation to water pollution. Bulletin of the Plankton Society of Japan 23: 31-49.

3. Manabe T, Ishio S (1991) Bloom of Coscinodiscuswailesii and D.O. deficit of bottom water in Seto Inland Sea. Marine Pollution Bulletin 23: 181184.

4. Yanagi T (1988) Preserving in the inland sea. Marine Pollution Bulletin 19(2): 51-53.
5. Zaitsev YP (1992) Recent changes in the trophic structure of the Black Sea. Fisheries Oceanography 1(2): 180-189.

6. Justic D, Rabalais NN, Turner RE, Dortch Q (1995) Changes in nutrient structure of river dominated coastal waters: stoichiometric nutrient balance and its consequences. Estuarine, Coastal and Shelf Science 40(3): 339-356.

7. Baric A, Marasovic I, Gacic M (1992) Eutrophication Phenomenon with special reference to the Kastela Bay. Chemistry and Ecology 6(1-4): 5168.

8. Morovic M (1983) Long term changes of transparency in the central Adriatic. Rapports et Proces-verbaux des Reunions. Commission internationale pour l'Exploration scientifique de la Mer Mediterranee 28(2): 181-182.

9. de Jonge VN, de Jong DJ (1992) Role of tide, light and fisheries in the decline of Zostera marina L. in the Dutch Wadden Sea. Netherlands Institute for Sea Research Publication Series 20: 161-176.

10. Conversi A, McGowan JA (1992) Variability of water column transparency, volume flow and suspended solids near San Diego sewage outfall (California): 15 years of data. Chemistry and Ecology 6(1-4): 133-147.

11.Conversi A, McGowan JA (1994) Natural versus human-caused variability of water clarity in the Southern California Bight. Limnology and Oceanography 39(3): 632-648.

12.Johanessen T, Dahl E (1996) Declines in oxygen concentrations along the eastern Skaggerak coast, 1927-1993; a signal of ecosystem changes due to Eutrophication? Limnology and Oceanography 41(4): 776-778.

13. White M, Gaffney S, Bowers DG, Bowyer P (2003) Interannual variability in Irish Sea turbidity and relation to wind strength. Proceeding of the Royal Irish Academy 130: 83-90.

14.Kratzer S, Buchan S, Bowers DG (2003) Testing long-term trends in turbidity in the Menai Strait, North Wales. Estuarine Coastal and Shelf Science 56(2): 221-226.

15. Bowers DG (2006) Menai Strait turbidity and co-variate surveillance. Marine Monitoring Report, No 22.

16. Alexandersson H, Tumenvirta H, Schmith T, Iden K (2000) Trends of storms in NW Europe derived from an updated pressure data set. Climate Research 14: 71-73.

17.Tuncer I (2017) Comparison of long term turbidity trends in different locations. Psychology Research 7(5): 297-304. 